ECONOMICS

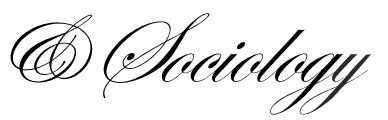

\author{
Jaroslav Belás, \\ Tomas Bata University in Zlin, \\ Zlin, Czech Republic, \\ E-mail:belas111@gmail.com
}

Anh Nguyen,

Tomas Bata University in Zlin,

Zlin, Czech Republic,

E-mail:anbnbu80@gmail.com

\author{
Luboš Smrčka, \\ University of Economics Prague, \\ Prague, Crech Republic, \\ E-mail:smrckal@use.cr. \\ Jozef Kolembus, \\ DTI University in Dubnica nad \\ Vábom, \\ Dubnica nad Váhom, Slovak \\ Republic, \\ E-mail:jozef.kolembus@gmail.com
}

\author{
Eva Cipovová, \\ The University of Finance and \\ Administration, \\ Prague, Crech Republic, \\ E-mail:evacipovova@gmail.com
}

Received: May, 2016

1st Revision: September, 2016

Accepted: November, 2016

DOI: $10.14254 / 2071-$

789X.2016/9-4/12

JEL Classification: A22
Belás, J., Nguyen, A., Smrčka, L., Kolembus, J., Cipovová, E. (2016), Financial Literacy of Secondary School Students. Case Study from the Czech Republic and Slovakia, Economics and Sociology, Vol. 9, No 4, pp. 191-206. DOI: 10.14254/2071789X.2016/9-4/12

\section{FINANCIAL LITERACY OF SECONDARY SCHOOL STUDENTS. CASE STUDY FROM THE CZECH REPUBLIC AND SLOVAKIA}

\begin{abstract}
Financial literacy is an important area of education for secondary school students, because appropriate management of personal finance creates preconditions for successful and quality life. In this article we examined the level of financial literacy of students of commercial academies in Czech Republic and Slovakia. Our results confirmed that the learning process in both countries has some reserves. The average value of correct answers regarding the savings was $16.33 \%$ in Slovakia and $21.33 \%$ in the Czech Republic, which can be classified as very low. Significantly improved results were shown by the respondents when it comes to consumer loans. The average value of correct answers in Slovakia was relatively high (87.76\%). In the Czech Republic, the average value of the correct responses was $61.33 \%$. The average value of correct answers on the use of payment cards abroad was relatively high both in Slovakia (77.55\%) and the Czech Republic $(73.33 \%)$. Our research, which was significantly more extensive than presented in this article, demonstrates that the intensity of interest in the socio-economic system is relatively low and students are not adequately motivated to be proactive. Therefore, we propose to create more room for intense use of advanced teaching methods in order to improve application skills of students. In this context, it is necessary to focus on promotion of personal initiative among the students.
\end{abstract}

Keywords: financial literacy, savings, consumer loans, payment card.

\title{
Introduction
}

Economic knowledge is an important part of education. Teaching economics at secondary specialized schools is of great importance because it prepares future adults comply with any profession (accountants, assistants, etc.), or continue studying at a university. 
Financial literacy should be an important area in education of secondary school students, because appropriate management of personal finances creates preconditions for successful and quality life.

In this article we examined the level of financial literacy of students of commercial academies in the Czech Republic and Slovakia.

This article has the following structure. In the theoretical section we define important terms and relationships, with which we work further on. In the next section we define scientific hypotheses and present the methodological approach and the data used, as well as the methods that were used in data processing. Next we explain the main results of the research. The part called Discussion presents the results of the researches, which were carried out in the countries of Visegrad quartet in the area of financial literacy. The reason is that these countries very closely collaborate in the field of science, research and education. In the conclusion of this article, we formulate the basic findings of our research.

The main benefit of our paper is the comparison of the financial literacy of students of commercial academies in the Czech and Slovak Republic based on the selected model examples. We were unable to find a similar comparison that deals with those countries in the scientific literature. At the same time, we compared these results with the results of the university students to find out if the university education significantly helps to improve financial literacy.

\section{Theoretical background}

\subsection{Cash, deposits and loans of households}

In deciding when and how much to save, households usually consider several factors: the level of income, the intended target savings, anticipated income that will be collected in the form of savings (which means, propensity to save). It applies in general, that the volume of household saving increases with the raise of an income. Families and individuals with higher incomes tend to have relatively higher savings and lower consumption in comparison with their total income than families with lower incomes (Rose, 1994).

The process of creating the savings cannot be precisely defined, since in addition to economic factors (economic growth, income, prices, interest) uneconomic factors (psychological, social, subjective - taste, fashion, expectations, traditions) are also involved, while a range of contradictory factors simultaneously operates in this process. Potential possibilities of creating savings in the economy can be expressed through formal saving function:

$$
S x=f\left(E, I, P c, I^{\prime}, T, F\right)
$$

where: Sx - savings, E - level of economy, I - income of economic operator, $\mathrm{Pc}$ - the price level and its dynamics, $\mathrm{I}^{\prime}$ - interest rate, $\mathrm{T}$ - subjective factors (for example, tastes, preferences, fashion, expectations, traditions), F - other factors, for example, psychological factors (Belás et al., 2010).

The issue of motives of indebtedness of households is not studied in detail in the literature. Rose (2002) defines two characteristics of consumer loans: they are sensitive to the economic cycle and are inelastic to interest rates. According to the author, the level of educational attainment is an important factor that significantly affects the tendency to indebtedness, notwithstanding the fact that more educated people tend to keep lending at reasonable balance in relation to the income. 
The causes of the use of external resources to finance the needs of individual clients can be seen in the following areas. Objective necessity of men at first place is to secure their own biological needs, especially the need for housing. Due to the high price of real estate, it is virtually impossible for certain income groups to save up the required amount within a reasonable time, so this is why they are taking out a mortgages or another loan from the banks. There is a time discrepancy between the subjective feeling of necessity to satisfy their needs and current income. Household needs are determined by a variety of subjective, social and psychological factors. It is obvious that individual needs are growing faster than the possibilities of their financing, resulting in a high interest in the loan financing practically all over the world. Positive expectations of their own incomes in the future may increase the level of optimism of an individual client who decides to increase its current consumption by using a bank loan, experience shows that customers are willing to borrow at favourable stage of the economic cycle, because they believe that their income is high and stable (crisis can bring a dramatic impact on their standard of living). Personal characteristics of the individual - in their personal way of living, some people express the greater tendency to indebtedness than other people. In this context, the importance of financial literacy of households, which largely determines the quality of financial decision of the client, individual preferences of the customers and a high degree of personal responsibility, is obvious. Marketing activities of commercial banks (intensive offer of the eye-catching products and business conditions) can encourage clients to flesh out their inhibitions and to consume today what they can earn up tomorrow by using the bank loan (Belás et al., 2010). Advertising can convince a man that without a new phone or a new plasma television he is not a full member of society and that the debts are safe, friendly and actually almost essential for a successful life (Balabán et al., 2011).

The way, how people can manage their money, determines the quality of their life, happiness, satisfaction and security. In this context, financial literacy is a very topical issue.

\subsection{Financial literacy, definition and meaning}

Financial literacy is a subject of study for many authors both in the world. Different authors emphasize different attributes of financial literacy.

Even though the importance of financial literacy has been widely acknowledged, there is a lack of consensus on financial literacy definition (Titko et al., 2015). However, it is believed that there has been a lot of discussion but little agreement on the conceptualization of financial literacy. Remund (2010) reviewed 100 resources and found that the definition of financial literacy involves five categories: (i) understanding financial concepts, (ii) being able to communicate about these concepts, (iii) ability to deal with personal finances, (iv) being good at making financial decisions and (v) being confident of making effective plans for future financial needs. However, other researchers and communities have not approved this definition. In a paper on this subject Huston (2010) reassessed 71 studies and concluded that nearly one-half of these studies described financial literacy as the financial knowledge. Others considered financial literacy to be something wider than knowledge, but they did not agree about additional components. Some claimed that money management skills must be a part of financial literacy. For instance, The President's Advisory Council on Financial Literacy (2008) defined financial literacy as "the ability to use knowledge and skills to manage financial resources effectively for a lifetime of financial well-being", a definition which is quite close to the one used by Jump Start Coalition for Personal Financial Literacy (2015).

However, other researchers believe that being able to make the right decisions is also an additional component. Specifically, in their study on debt literacy, Lusardi \& Tufano (2015) define it as "the ability to make simple decisions regarding debt contracts, in particular how one applies basis knowledge about interest compounding, measured in the context of 
everyday financial choices". Because of the difficulty in defining, financial literacy is a complicated phenomenon and it is tricky to measure directly. This means that a single question cannot recognize if a person is financially literate. As a result, Atkinson and Messy (2011) prove in their article that a comprehensive set of questions should be prepared so as to examine the understanding, as well as analyse attitudes and financial behaviours.

According to Lusardi (2012), financial literacy consists of three main pillars:

1. Financial ability and behaviour - this term is elaborated to various details in this article in order to prove, it is very broad and there is a correct response to what it is actually very individual and depends on the circumstances.

2. Financial knowledge - once again highlights the concept of the notion that the knowledge is never complete, and it is needed throughout life, with regard to the changing conditions, to be constantly replenished.

3. State support - it requires the cooperation of relevant financial institutions and the state to steadily improve the level and the quality of the two previous points.

According to Bay, Catasu, and Johed (2014), financial literacy is perceived either as (1) an individual capability that can be acted upon in relation to experience, vocabulary and skills (the autonomous model), or (2) a socially situated issue where financial literacy in itself must always be debated (the situated model).

"Financial literacy is a set of knowledge, skills and values and attitudes of citizens that are required to financially secure themselves and their families" (Balaban et al., 2011).

As it is stated in the document of the Ministry of Education, Science, Research and Sport of Slovakia and Slovak Ministry of Finance financial literacy is the ability of individual to use the knowledge, skills and experience to effectively manage own resources in order to ensure lifelong financial security of them and their households. Financial literacy is not an absolute condition, it's a continuum of capabilities that are subject to variables such as age, family, culture or place of residence. Financial literacy denotes a state of continuous development to enable each individual to respond effectively to new personal events and constantly changing economic environment. Taking into consideration the limited experience and not yet adopted desired degree of responsibility, the current high school graduate will not exhibit the same degree of knowledge in the field of personal finances than older, financially literate adult. However, financially literate graduates of secondary schools, should at least generally understand all key aspects of personal finance. These graduates will be assured that they would be able to independently find and use the information required for specific financial challenges they may face themselves from time to time (Ministry of Education, Science, Research and Sport of Slovakia, Ministry of Finance of Slovakia, 2014).

Lusardi and Tufano (2015) emphasize that financial literacy is important because it has been linked to saving behaviour and portfolio choice. The model by Jappelli and Padula (2015) implies that financial literacy accumulated early in life is positively correlated with the individual's wealth and portfolio allocations in later life. Financial literacy may have an impact on financial decision-making (Disney et al., 2015), because learning about finance is necessary in order to make the right financial decisions (Calcagno and Monticone, 2015) and invest the most effectively (Capuano and Ramsay, 2011), which leads to a gradual increase in their wealth (Jappelli and Padula, 2013; van Rooij et al., 2011; Lusardi and Mitchell, 2011).

Less knowledgeable people make more costly decisions (Lusardi and Tufano, 2015). Borrowers with poor financial literacy hold higher shares of high cost credit (such as home collected credit, mail order catalogue debt and payday loans) than those with higher literacy. Individuals with poor financial literacy are more likely to lack confidence when interpreting credit terms, and to exhibit confusion over financial concepts. They are also less likely to engage in behaviour which might help them to improve their awareness of the credit market (Disney and 
Gathergood, 2013). Less knowledgeable individuals also report that their debt loads are excessive or that they are unable to judge their debt position (Lusardi and Tufano, 2015).

Respondents with lower level of financial literacy are more likely to have costly mortgages and are less likely to refinance their mortgages during a period of falling interest rates (Lusardi and Tufano, 2015). In this context authors state that low level of debt literacy is the norm, and understanding of the basic mechanics of debt is especially limited among the elderly, females, certain minorities, and people with lower incomes and wealth. According authors females - both young and old - exhibit substantially lower debt literacy than males.

According to Balaban et al. (2011) the need for training of citizens in financial literacy has increased substantially due to the fact that many citizens have no idea (have already lost, or even have not had it at all) regarding the subject of money, and almost do not have an idea about the current status of their personal or, respectively, family finances. The basic concepts of finance are equally absent. For example, many people will not perceive the fundamental difference between $\%$ p. a. and $\%$ p. $\mathrm{m}$, the annual percentage rate of costs is still not the basic information required for the life, living on credit has become standard practice, and etc. Surveys and measuring of the level of financial literacy of adults and students clearly demonstrate that. More than $2 / 3$ of citizens have not developed neither personal nor family budget at all and have no idea about the current state of their finances. Thanks to vanishing physical transfer of money (cash payments), not only the young but also the middle generation misses track of their own money. In this context Belás et al. (2008) outlines the basic reasons for the introduction of payment cards - psychological aspects of sales, which can be characterized as a state where the client's incline to purchases using payment cards is more intense in comparison to paying by cash; the research in this area has confirmed that the person who signs the relevant document does not feel such damage as the waiver of the banknotes and coins that physically leave the wallet, and this has considerably more intense perception, and therefore such a person buys a lot more with the payment card.

Financial literacy is the subject of many studies that examine the attributes of financial literacy and at the same time confirm or refute dependences of many aspects affecting the financial literacy of middle school students.

Jump Start Surveys (Mandell, 2006) showed that high school students who play a stock market game are significantly more financially literate than those who do not. This implies that which classes are interactive, relevant, and fun may be more effective than those that are purely didactic.

The literature suggests that there is a pretty close association between financial literacy and household welfare. Studies indicate that households with less financial knowledge or literacy, do not tend to plan their retirement, receive lower level of assets (Lusardi and Mitchell, 2007), and usually borrow at higher interest rates.

Various types of questionnaires were conducted to examine the level and the spread of financial literacy. Results of the study by Lusardi and Mitchell (2007) show that people with the low level of education, females, African-Americans and Hispanics demonstrate low level of financial literacy, which subsequently influence financial decision-making. Results of the study discovered that these examined respondents fail to properly plan their retirement period, are less involved in the stock market operations and have poor borrowing behaviour, possibly due to the lack of understanding in the field of basic financial knowledge (Lusardi, Mitchell, 2007).

Mahdzan and Tabiani (2013) examined the influences that affect individual saving with the focus on financial literacy in the Malaysian region. Their research shows that people have poor knowledge about bonds, and risk-return issues. Although the results specify that individuals have a relatively good level of basic financial knowledge about the calculation of interest rates and/or percentages, and knowledge on relative riskiness of financial assets, etc. 
Results also indicate that older people do have some saving, and the other factors remain to be constant in this group of respondents.

The study by Agnew and Harridon (2015) presented the finding defined in compatison of the university students from England and New Zealand and the students from other countries, stating that males overcome women on financial literacy quizzes. While males overcome females on a simple compound interest question in both countries, both genders in New Zealand overcome their English counterparts on questions relating to credit card interest rates, income tax rates and more complex compound interest questions. Approaches to student debt were also compared between two countries, where it was found that among the English sample females less significantly previewed the future advantages of higher education in comparison to their male colleagues.

Mandell (2008) in two year cycles realized five national examinations of seniors of high schools during the period from 1997 to 2006 with the aim to measure the financial literacy of young American adults. The results show low level of capability to make ageappropriate financial decisions in their own interests. Students from the families with more sufficient financial resources tend to be significantly more financially literate than those from families that are less wealthy, thereby deteriorate the inequality of economic welfare between families. Moreover, high school classes in personal finance and money management did not prove the effectiveness in increasing levels of financial literacy.

This study (Jang et al., 2014) provides an assessment of financial literacy between Korean and U.S. high school students. The test was conducted on a sample of 1478 students from 40 high schools in South Korea and U.S. The results of this comparison showed that Korean students tended to be stronger in such contents as "earning income". Moreover, the assessment of financial literacy based on Bloom's cognitive levels specified that Korean students' financial literacy was comparatively stronger at the cognitive level of knowledge, but relatively weaker at higher cognitive levels of comprehension and its application.

Financial literacy on young Italian 15 years old students tested Montanaro and Romagnoli (2016). They found out that there is a hudge gap between Italians and average of OECD in financial literacy. About 40 per cent of the gap is generated by students from relatively rich families whoos are anyway characterised by moderate financial literacy. Researchers tracked back the reason of the gap to lack of involvement of students in financial matters and money.

Interesting resulst has a research of financial literacy of high-school students in Germany (Erner et al., 2016). Basic of financial literacy is related mostly to mathematical skills but sophisticated financial literacy is more related to foreign language skills and general cognitive aptitude. Lower financial literacy according to this research have female students and students with low level of integration.

Importance of high school financial education proves also research at 15 universities in United States (Gutter et al., 2016). Financial behaviour of university students vary according to state mandates on financial education at high school. The standards and attitude of states in United States are different. According to Walstad, Tharayil, and Wagner (2016) does not have every state included financial literacy in their standards or as a requirement for graduation.

Impact of financial literacy high-school students shows also long-term research based on Family Financial Socialization Theory (Danes et al., 2016). Authors of study found out competency-based learning developed a better foundation of financial knowledge. They also have better financial behaviours. One of the most important part of financial education is "to perceive a specific financial behaviour as relevant, desirable and feasible in their social environment". Social environment is crucial factor to long-term effect. 


\section{Aim, Methodology, and data}

The aim of the article is to analyse the selected attributes of financial literacy of students of the secondary schools in the Czech Republic and Slovakia and to suggest possible innovative approaches in teaching process in order to increase the level of students' applicational skills. In our research we investigated the differences in skills application among school students in Slovakia and the Czech Republic and the differences between the genders.

Three scientific hypotheses were set by the method of expert estimation:

H1: The average rate of correct application of theoretical knowledge in the selected areas of financial literacy in the Czech Republic and Slovakia is relatively low, and is less than $60 \%$.

$\mathrm{H} 2$ : There are no statistically significant differences between the correct answers of Czech and Slovak students.

H3: There are no statistically significant differences between the correct answers of men and women in Slovakia and the Czech Republic.

Structured interviews with nine high school teachers in the Czech Republic and Slovakia were conducted as a part of the research. We found that the course called Banking is taught in the range of approximately 70 hours in both countries. The aim of this course is the practical application of the knowledge of banking in economic problems's solving by the classic and activating methods. The content of the course includes banking system, bank deposit products, loan products of banks, financial markets and international financial institutions. we Our questionnaire was based on these discussions.

Five structured interviews with the university teachers were conducted as a part of our research. We were interested in university teachers' evaluation of the situation, because many of the high school graduates continue their studies at the university level. We present the results of a short survey from one Czech university in the discussion related to this article. This secondary research was conducted on a sample of 37 respondents.

Main empirical research was conducted on a sample of 173 students of commercial academies in Slovakia (98 in total, 72 females, 26 males) and the Czech Republic (75 in total, 52 females, 23 males).

We have chosen three basic scenarios of financial literacy in our research: the process of creating savings, the process of obtaining external finances through the bank loan, the process of paying for goods and services. We investigated the way of solving of presented model situation scenarios by our respondents. The obtained data were evaluated through Pearson statistics and such tools of descriptive statistics as arithmetic average and percentages.

When calculating $\chi 2 \mathrm{a}$ p-value we've used freely accessible calculator, available at: http://www.socscistatistics.com/tests/chisquare2/Default2.aspx.

When quantifying the differences within the correct answers, we used test of Z-score available at: http://www.socscistatistics.com/tests/ztest/Default2.aspx.

The obtained results were explained and compared with theoretical sources.

\section{Results and Discusion}

\section{Model situation 1: Making savings.}

The approach to creating monetary savings represents an important area of financial literacy. The ability to manage money means that the individual is better prepared for life and the higher quality of life because it is not under pressure of paying its obligations.

Question 1: At what stage of the economic cycle it is advisable to save money? 
The correct answer is the No. 2 in Table 1, because it is economically rational to save money when people have higher salaries, which usually happens in the time of economic expansion.

Table 1 presents the responses of the respondents to the question examining the propensity to save households of Slovak (SR) and Czech (CZ) students.

Table 1. Evaluation of the responses of the respondents in the area of savings

\begin{tabular}{|c|c|c|c|}
\hline $\begin{array}{l}\text { Model situation 1: Question: At what stage of } \\
\text { Economic cycle it is advisable to save money? }\end{array}$ & $\begin{array}{l}\text { SR } \\
\text { Together } \\
\text { M/W }\end{array}$ & $\begin{array}{l}\text { CZ } \\
\text { Together } \\
\mathrm{M} / \mathrm{W}\end{array}$ & $\begin{array}{l}\text { p-value } \\
\text { SR/CZ } \\
\text { SR: M/W } \\
\text { CZ: M/W }\end{array}$ \\
\hline $\begin{array}{l}\text { 1. In the recession phase because of the need } \\
\text { To prepare for bad times }\end{array}$ & $\begin{array}{c}54 \\
18 / 36\end{array}$ & $\begin{array}{c}26 \\
5 / 21\end{array}$ & - \\
\hline $\begin{array}{l}\text { 2. In the phase of expansion, because people have higher } \\
\text { salaries* }\end{array}$ & $\begin{array}{c}16 \\
6 / 10\end{array}$ & $\begin{array}{c}16 \\
6 / 10\end{array}$ & $\begin{array}{l}\mathbf{0 . 4 0 0 9} \\
\mathbf{0 . 2 7 5 7} \\
\mathbf{0 . 5 0 2 9} \\
\end{array}$ \\
\hline 3. Saving does not make sense & $\begin{array}{c}0 \\
0 / 0\end{array}$ & $\begin{array}{c}3 \\
1 / 2 \\
\end{array}$ & - \\
\hline 4. It depends on the momentary revenue and expenditure. & $\begin{array}{c}28 \\
2 / 26 \\
\end{array}$ & $\begin{array}{c}30 \\
11 / 19 \\
\end{array}$ & - \\
\hline $\begin{array}{l}\text { The average value of correct answers in } \% \\
\chi^{2}=9.9877 / p \text {-value }=0.0187\end{array}$ & $\begin{array}{l}\mathbf{1 6 . 3 3} \\
23.08 \\
13.89\end{array}$ & $\begin{array}{l}21.33 \\
26.09 \\
19.23\end{array}$ & - \\
\hline
\end{tabular}

Explanatory notes: $\mathrm{M}-\mathrm{men}, \mathrm{W}-$ women.

Source: own research.

The average value of correct answers was $16.33 \%$ in Slovakia and $21.33 \%$ in the Czech Republic, which can be classified as a very low.

The value of $\chi^{2}$ and $p$-value $(9.9877 / 0.0187)$ confirmed that there are statistically significant differences in the overall responses from Slovakia and the Czech Republic. These differences are caused by different structure of wrong answers.

The values of the test criteria ( $p$-value $=0.4009 / 0.2757 / 0.5029$ ) confirmed that there were no statistically significant differences in correct answers of students from Slovakia and from the Czech Republic and there are no statistically significant differences in correct answers between the genders in the reviewed countries.

Model situation 2: Loans from commercial banks.

Households also use external funding for their expenses. The proper selection of bank products can save the money for them.

Question 2: You need to borrow $€$ 3,350 for one year. First financial institution offers the following conditions: interest rate of $8.95 \% \mathrm{p}$. m. under the of payment of the fee of 20 EUR. Second financial institution offers the following conditions: interest rate of $10.99 \%$ p. a. without charges for granting a loan. Which offer would you choose?

The correct answer is No. 2. The correct answer is apparent from a periodicity of interest. In the first case it is a monthly interest rate, in the second case it is the annual interest rate.

Table 2 presents the answers of the respondents to the question examining the ability of students to choose a better financial offer in the credit area.

The average value of the correct answers in Slovakia is relatively high $(87.76 \%)$ and is at an average level (61.33\%) in the Czech Republic. 
The value $\chi^{2}$ and $\mathrm{p}$-value confirmed that there are statistically significant differences in the overall despondences of the respondents from Slovakia and from the Czech Republic.

Table 2. Evaluation of respondents' answers when choosing a loan product

\begin{tabular}{|c|c|c|c|}
\hline $\begin{array}{l}\text { Model situation 2: You need to borrow } € 3,350 \text { for one year. } \\
\text { First financial institution offers the following conditions: } \\
\text { interest rate of } 8.95 \% \text {. m. under the of payment of the fee of } \\
20 \text { EUR. Second financial institution offers the following } \\
\text { conditions: interest rate of } 10.99 \% \text {. a } \text {. without charges for } \\
\text { granting a loan. Which offer would you choose? }\end{array}$ & $\begin{array}{l}\text { OA SR } \\
\text { Together } \\
\text { M/W }\end{array}$ & $\begin{array}{l}\text { OA CZ } \\
\text { Together } \\
\text { M/W }\end{array}$ & $\begin{array}{c}\text { p-value } \\
\text { SR/CZ } \\
\text { SR: M/W } \\
\text { CZ: M/W }\end{array}$ \\
\hline 1. The loan from the financial institution A & $\begin{array}{c}12 \\
2 / 10\end{array}$ & $\begin{array}{c}29 \\
9 / 20\end{array}$ & - \\
\hline 2. A loan from a financial institution B. & $\begin{array}{c}86 \\
24 / 62\end{array}$ & $\begin{array}{c}46 \\
14 / 32\end{array}$ & $\begin{array}{c}0.00 \\
0.4065 \\
0.9601\end{array}$ \\
\hline $\begin{array}{l}\text { The average value of correct responses in } \% \\
\chi^{2}=\mathbf{1 6 . 4 0 2 1} / \mathbf{p} \text {-value }<0.01\end{array}$ & $\begin{array}{l}\mathbf{8 7 . 7 6} \\
92.31 \\
86.11 \\
\end{array}$ & $\begin{array}{l}\mathbf{6 1 . 3 3} \\
60.87 \\
61.54 \\
\end{array}$ & - \\
\hline
\end{tabular}

Source: own research.

The value of the test criteria has confirmed that there are statistically significant differences in correct answers of students from Slovakia and from the Czech Republic. We found that students from Slovakia presented better application of skills in this area, because they were able to choose a better bank product. We also found that there were no statistically significant differences in correct answers between the genders. This means that males and females are equally successful in choosing the right bank loan in both countries.

Model situation 3: Payment abroad.

For proper management of money households need to know the pricing policy of commercial banks, because choosing the right banking product saves them money.

Question 3: Imagine the following situation: You're in a country where the payments are in the US dollars. You want to buy pants that cost $\$ 100$. What form of payment would you choose, provided that you have no dollars in cash?

The correct answer is No. 2. The correct answer results from the pricing policy of commercial banks. Banks use non-cash transactions in foreign exchange asset sales, which is more advantageous than cash sell rate. When getting cash from the ATM many banks charge a fee for withdrawals from an ATM in another country.

Table 3 presents the results of the research in the field of international payments.

The average value of the correct answers in Slovakia $(77.55 \%)$ and the Czech Republic $(73.33 \%)$ is relatively high.

The value $\chi^{2}$ and $p$-value confirmed that there were no statistically significant differences in the overall Respondents from Slovakia and from the Czech Republic.

The value of the test criteria confirmed that there are no statistically significant differences in correct answers of students from Slovakia and the Czech Republic, and there are no statistically significant differences in correct answers between the genders. 
Table 3. Evaluation of respondents' answers on foreign payments

\begin{tabular}{|c|c|c|c|}
\hline $\begin{array}{l}\text { Model Situation 3: Imagine the following situation: You're in a } \\
\text { country where all payments are in the US dollars. You want to } \\
\text { buy pants that cost } \$ 100 \text {. What form of payment would you } \\
\text { choose in case that you have no dollars in cash? }\end{array}$ & $\begin{array}{l}\text { OA SR } \\
\text { Together } \\
\text { M/W }\end{array}$ & $\begin{array}{l}\text { OA CZ } \\
\text { Together } \\
\text { M/W }\end{array}$ & $\begin{array}{l}\mathrm{p} \text {-value } \\
\mathrm{SR} / \mathrm{CZ} \\
\mathrm{SR}: \mathrm{M} / \mathrm{W} \\
\mathrm{CZ}: \mathrm{M} / \mathrm{W}\end{array}$ \\
\hline 1. I will take my money from an ATM & $\begin{array}{c}2 \\
0 / 2\end{array}$ & $\begin{array}{c}4 \\
1 / 3 \\
\end{array}$ & 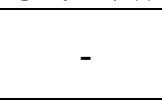 \\
\hline 2. I will pay with payment card* & $\begin{array}{c}76 \\
22 / 54\end{array}$ & $\begin{array}{c}55 \\
14 / 41\end{array}$ & $\begin{array}{l}0.5222 \\
0.3125 \\
0.1052\end{array}$ \\
\hline 3. It doesn't matter & $\begin{array}{c}20 \\
4 / 16 \\
\end{array}$ & $\begin{array}{c}16 \\
8 / 8 \\
\end{array}$ & - \\
\hline $\begin{array}{l}\text { The average value of correct responses in } \% \\
\chi \mathbf{2}=\mathbf{1 . 4 4 5 3} / \mathbf{p} \text {-value }=\mathbf{0 . 4 8 5 5}\end{array}$ & $\begin{array}{l}77.55 \\
84.62 \\
75.00\end{array}$ & $\begin{array}{l}73.33 \\
60.87 \\
78.86\end{array}$ & - \\
\hline
\end{tabular}

Source: own research.

Evaluation of the hypotheses:

H1: The average rate of correct application of theoretical knowledge in the selected areas of financial literacy in the Czech Republic and Slovakia is relatively low, and is less than $60 \%$.

Evaluation: H1 was not confirmed in Slovakia, since the average value of the correct answers reached $60.55 \%$. H1 was confirmed in case of Czech students because the average value of the correct answers reached $52 \%$.

$\mathrm{H} 2$ : There are no statistically significant differences between the correct answers of Czech and Slovak students.

Evaluation: $\mathrm{H} 2$ was not confirmed. We found that there are statistically significant differences in the model examples 1 and 2 in the responses of the students from Slovakia and the Czech Republic.

H3: There are no statistically significant differences between the correct answers of men and women in Slovakia and the Czech Republic.

Evaluation: H3 was confirmed. We found that there are no statistically significant differences between the correct answers of men and women in Slovakia and the Czech Republic.

The next part of the research compares the results of secondary school students and the results of the students of the Czech university. Some interesting results were identified. Secondary school students were more successful than students of the 1 st year of study at the university in the solvation of the model examples \#1 and \#2, and presented the similar results in addressing model example \#3.

A part of the research was devoted to the survey of the use of modern teaching methods. Based on structured interviews, we found that the intensity of use of these methods is relatively low, the average is at around $35 \%$ of the total amount of teaching time in Slovakia and $43 \%$ of the total amount of teaching time in the Czech Republic.

According to the results of financial literacy testing of OECD PISA 2012, young people in Slovakia have insufficient knowledge about finance and management. According to several experts, it is a business card of educational institutions, and the level of education in Slovakia itself. In this study Slovak students presented the literacy level in the financial performance at the value of 470 points (average performance of students in OECD countries 
was at the level of 500 points). Worse results were only shown by the students from Italy and Colombia (www.svet-komunikacie.sk).

The survey ING Slovakia brought an interesting finding that Slovaks blindly believe in themselves in the issue of dealing with money. According to this research, carried out in 2012 , up to $80 \%$ of Slovak respondents were convinced that they have sufficient knowledge of finances, but only $9 \%$ of the respondents we able to correctly answer the the test questions (www.nextfuture.sk).

According to Vravec (2014) Slovak population can be divided into two basic groups: those who consciously or unconsciously apply the basic principles of financial literacy in their lives; and those who do not have a slightest idea of how to effectively control and manage their personal finances and assets, do not analyse their financial situation, decide to chaotically and often irrationally, and think that financial literacy is not important for them. The most important differences between these two groups of the population are summarized in Table 4.

Table 4. Differences between defined groups of population in Slovakia according to their approach to financial literacy

\section{People who apply basic principles of financial literacy}

Take responsibility for their own lives and they actively manage and plan.

Establish their goals, especially economic, are trying to do more to achieve them.

They focus on their own qualities and strengths and know how to use them effectively.

They firstly see an opportunity in case of economic or financial problems.

They work on constant growth of their assets and property, pro-actively save and invest, and spend wisely.

They put emphasis and constantly work on their own education.

They think ahead, plan, invest and try to diversify revenues and investments.

They borrow judiciously, use loans effectively and devote proper attention to their repayment.

They preventively create a sufficient financial reserve for unexpected situations.

They actively manage their assets
People who do not apply basic principles of financial literacy

They believe in chance and fate, transfer their responsibilities to other entities (state, relatives, etc.).

They live from day to day without a vision and objectives, have no financial and economic objectives.

They can not use their strengths and underestimate themselves, they are afraid to take action and implement their plans.

All economic problems are difficult to overcome, obstacles prevent them from being successful.

They follow only immediate income, spend a lot to immediately have a high standard of living.

They do not learn enough, and feel that they already know everything important and do not need to study further.

Live for today, do not have financing plans and objectives, do not invest and fail to diversify risk. They get into debt very quickly, they do not use credit effectively and usually have problems with the repaiment.

They do not make any financial or other reserves for unforeseen situations.

Finances and their management do not interest them. When they have no money, they start to look for reasons.

Source: Vravec (2014).

According to Vravec (2014) financial and economic education, knowledge and skills, the awareness of individuals about the value of the money, the way how to earn them, to 
manage, administer and use them are essential for a successful and happy life. Underestimating the importance of financial management by an individual, financial literacy of individuals or households is therefore incomprehensible and unforgivably wrong and its consequences will be felt throughout the entire society (Vravec, 2014).

Defined differences between these groups of people are a reflection of different attitudes to life of these social groups, which is a result of their life philosophy. In this context, it is clear that the issue of financial literacy is not only economic, but caused by the other factors, such as: the nature of man, the level of education in the family, traditions, emotions, morality. Many cases from the real life confirm that the selection of unsuitable economic solutions was determined rather by non-economic factors than economic. In this context, for example, Jappelli and Padula (2013) state that financial literacy is a choice.

Luksander, Béres, Huzdi and Németh (2014) examined the factors that affect the financial literacy of young people with the higher education. The study was conducted in Hungary among around of 38000 students. The results show a huge difference in relation to measured criteria. Males, older people, people with a higher income and young people whose income is covered by their family, which is affected only slightly, are typically categorised to the group of people with the advanced level of financial literacy. The results indicate that the financial-economic knowledge obtained during the process of higher education has a higher impact on the financial knowledge of young people; on the other hand, this type of training and studies does not have any significant effect. The studies also revealed that the teaching of financial-economic topics in secondary school does not have any impact on the level of young people's financial knowledge. The students, who contributed their opinions in the research, achieved better results in answering theoretical questions than in case of practical questions. It is also true that males, older people, those who attend economic studies or these kinds of courses at their university know more about financial matters. When investigating the educational criteria we found that the economic nature of the training significantly relates with the practical knowledge, while the number of semesters dedicated to the study of subjects related to economics has a stronger positive impact on theoretical knowledge. The results reveal the need for a reform in the teaching of financial-economic knowledge and the introduction of programmes that can generate interest in financial matters.

It would be interesting for compare the mentioned research by Kantnerová (2013), which took place in 2013 and was aimed to the analysis of the needs of financial literacy and financial skills among youth in the Czech Republic. The questionnaire was aimed on the adolescents aged 16-33 years. The total number of respondents was 658 . Only $30.6 \%$ of all respondents make their choice of the financial institution according to its credibility. $30.5 \%$ of them made the selection in accordance to the maintenance fees, which are a burden of the family budget. It was also found that when choosing a loan, the respondents were giving favor to credit costs $-30.4 \%$ to APR, $26.1 \%$ to monthly repayments and only $23.3 \%$ to the interest rate. Knowledge of the family budget was presented by the $79.3 \%$, of the respondents, which can be assessed as insufficient and therefore it is necessary to increase efforts in raising the knowledge of children in schools. In case of reading the contracts, which is generally considered to be a major problem and the cause of a number of cases, it was found that the contracts are read by only $1.5 \%$ of respondents. It is hard to determine whether the responses were influenced by the knowledge of the issue. In case of the knowledge of the contract $89.9 \%$ of the respondents stated that they knew about the penalties that await them in the event of default. The remaining $10 \%$ is still a high enough proportion to ensure that a number of respondents would fall into the debt trap. $12.4 \%$ of respondents state that they do not know what to do in case of inability to repay loans. In contrast, $81.8 \%$ of respondents state that in case of insolvency they would know what to do and they would discuss the next steps with the lender. 
Polish research presented the similar results as the Czech one. Financial literacy has greatly decreased after 2008 due to the crisis, which forced banks to introduce new products and the majority of the population would not perceive information from the massive advertising campaigns. Educational program of the National Bank of Poland held up to 2012 indicate that the state of knowledge of the Polish population in the field of financial literacy is unsatisfactory. Polish National Bank presents the increase of the financial literacy as a tool for the improvement of the financial system. It sees a potential for economic growth of the country in the increased level of the financial literacy (Kantnerová, 2012).

Poland as well as many other countries adopted a national strategy for financial education (NSFE), which establishes the standards for financial education. According to the provided data it was found that financial literacy is higher among males and people aged 34 54 years old, and people with income of more than 2000 PLN. On contrary the lowest level of financial education was presented by the poorest group of the population, which is mostly at risk because it is not able to choose the right financial strategy for their families (Kantnerová, 2012).

The latest surway of financial literacy of adults in Czech Republic from the year 2015 provided by Ministry of Finance of the Czech Republic (www.psfv.cz) which is the part of research of financial literacy in OECD countries shows that the younger population (up to 29 years old) has lower financial knowledge and especially economic $\mathrm{r}$ (esponsibility than older people. According the research the reason is that particularly students don't care about financial matters and they don't take the family finance decisions so they have lack of experience. On the other hand the younger generation sets financial objectives more than the others.

Not surprising results of the research shows that people with higher income and people with higher education level have also higher level of financial literacy. But there is no significant difference in financial knowledge between men and women.

Financial knowledge is highly important part of financial literacy. There is a significant relation between financial knowlede and economic responsibility that leads to healthy personal or family finance. That points out the importance of financial education at schools.

Our research, which was significantly more extensive than presented in this article, demonstrates that the intensity of interest in the socio-economic system is relatively low and students are not adequately motivated to be proactive. Therefore, we propose to create more room for intense use of advanced teaching methods in order to improve application skills of students. In this context, it is necessary to focus on promotion of personal initiative among pupils. This is the main and most important finding of our research.

\section{Conclusion}

The results of our research showed that the ability of secondary school students to correctly apply theoretical knowledge and manage their own money has some reserves.

The significant finding is that the secondary school students have a wrong approach to the creation of cash reserves in the form of savings. In our model example the number of correct answers was around $20 \%$, which is an alarming trend due to the special importance of savings in financial management of households. Students from commercial academies presented better application skills in the field of the evaluation of the advantages of the use of consumer credits and payment cards in foreign payments.

Our results show that the intensity of the use of new approaches to teaching economics in secondary schools is not adequate to the current dynamics of the development of socio- 
economic system, and therefore secondary schools should actively seek and implement new approaches, forms and methods in the educational process.

Based on the theoretical analysis of this issue and the results of our own research, we have developed a basic conceptual proposal to improve application skills of students in secondary schools.

A. We propose to create more room for increased use of modern teaching methods in order to improve application skills of students. In this context, it is necessary to focus on the use of modern methods that promote creativity and initiative of students (case studies, problems solution method and brainstorming). The current method of teaching traditionally focused on gaining of encyclopaedic knowledge, that can be more use full in the knowledge competition, than the real life.

B. Search for methods aimed on the encouraging of personal initiatives especially of the gifted students since they are likely to be active and motivate other students by this. Activities: project of the gifted students, manager's day, business grants, grants from major schools or companies with the similar projects. The main objective of these projects should be the strengthened application of the skills of the students in their chosen economic field through individual activity beyond the standard educational process: getting of theoretical knowledge, experience in the real company, developing and implementing of their own projects. The project must contain suitable form of rewards for students who submit a successful project, respectively, prove their managerial talent (eg. financial reward or promise of future employment).

C. We propose to prepare and implement quality project of Financial Literacy. This project should be comprehensive and target-oriented. The project should include interpretation of the teacher on financial literacy, the processing of case studies and expert presentation, for example: executor, psychologist, judge, banking specialist, as it is necessary not only to rationally perceive the importance of this issue, but also to achieve emotional perception, or eventually to alert about tough sanctions and consequences for the life of the individual.

The presented research, like other scientific researches, has its certain boundaries and limits, due to the fact that it was conducted on a limited sample of respondents in a specific area.

Nevertheless, it can be assumed that it could be an interesting inspiration for this area of scientific knowledge and practical teaching methods in teaching economic subjects in secondary schools.

\section{References}

Agnew, S. and Harrison, N. (2015), Financial literacy and student attitudes to debt: A cross national study examining the influence of gender on personal finance concepts, Journal of Retailing and Consumer Services, 25, pp. 122-129.

Atkinson, A. and Messy, F. A. (2011), Assessing financial literacy in 12 countries: an OECD/INFE international pilot exercise, Journal of Pension Economics and Finance, 10(4), pp. 657-665.

Balabán, Z. et al. (2011), Slabikář finanční gramotnosti, Praha: Cofet.

Bay, Ch., Catasu, B., and Johed, G. (2014), Situating financial literacy, Critical Perspectives on Accounting 25, pp. 36-45.

Belás, J. et al. (2008), Komerčné banky. Teória, riadenie, obchody, Žilina: Georg.

Belás, J. et al. (2010), Management komerčných bánk, bankových obchodov a operácií, Žilina: Georg. 
Calcagno, R. and Monticone, Ch. (2015), Financial literacy and the demand for financial advice, Journal of Banking \& Finance 50, pp. 363-380.

Capuano, A. and Ramsay, I. (2011), What causes suboptimal financial behavior? An exploration of financial literacy, social influences and behavioral economics, $A n$ Exploration of Financial Literacy, Social Influences and Behavioral Economics (March 23, 2011). U of Melbourne Legal Studies Research Paper, (540), Retrieved from http://papers.ssrn.com/sol3/papers.cfm?abstract_id=1793502.

Danes, S. M., Deenanath, V. and Yang, Y. (2016), Evaluation of Financial Literacy Development of High School Students: A Longitudinal Mixed Methods Study, International Handbook of Financial Literacy, pp. 425-447.

Disney, R., Gathergood, J., and Weber, J. (2015), Credit counseling: a substitute for consumer financial literacy? Journal of Pension Economics and Finance, 14, pp. 466-491.

Erner, C., Goedde-Menke, M. and Oberste, M. (2016), Financial literacy of high school students: Evidence from Germany, The Journal of Economic Education, pp. 95-105.

Gutter, M. S., Copur, Z. and Garrison, S. (2016), Do the Financial Behaviours of College Students Vary by Their State's Financial Education Policies? International Handbook of Financial Literacy, pp. 213-247.

Huston, S. J. (2010), Measuring financial literacy, Journal of Consumer Affairs, 44(2), pp. 296-316.

Jang, K., Kahn, J., and Park, H. J. (2014), Comparison of financial literacy between Korean and U.S. high school students, International Review of Economics Education, 16(PA), pp. 22-38.

Jappelli, T. and Padula, M. (2013), Investment in financial literacy and saving decisions, Journal of Banking \& Finance 37, pp. 2779-2792.

Jappelli, T. and Padula, M. (2015), Investment in financial literacy, social security, and portfolio choice, Journal of Pension Economics and Finance, 14, pp. 369-411.

Jump Start Coalition for Personal Financial Literacy (2015), National standards in K-12 personal finance education, $4^{\text {th }}$ Edition, retrieved from http://www.jumpstart.org/assets/files/2014_NationalStandardsBook-WEB.pdf

Kantnerová, L. (2013), A Short study on the financial literacy, In: Finance and the performance of firms in science, education and practice [online], Zlin: Tomas Bata University in Zlin, pp. 314-323 [cit. 2016-02-20].

Kantnerová, L. (2012), Finanční gramotnost v České, Polské a Slovenské republice [online], 1. České Budejovice: Jihočeská univerzita v Českých Budejovicích, 2012 [cit. 2016-0220], retrieved from: https://www.pf.jcu.cz/stru/katedry/m/knihy/Financial_Literacy.pdf.

Luksander, A., Béres, D., Éres, K., Huzdik, K., and Némeht, E. (2014), Analysis of the Factors that Influence the Financial Literacy of Young People Studying in Higher Education, Public Finance Quarterly, (2), pp. 22-34 [cit. 2016-02-17], retrieved from: https://www.asz.hu/storage/files/files/public-finance-quarterlyarticles/2014/a_luksandera_2014_2.pdf.

Lusardi, A. (2012), Financial literacy or financial capability? In: Financial literacy and ignorace [online] [cit. 12.9.2012], retrieved from: http://annalusardi.blogspot.cz/.

Lusardi, A. and Mitchell, O. S. (2011), Financial literacy around the world: an overview, Journal of Pension Economics and Finance, 10(04), pp. 497-508.

Lusardi, A. and Mitchell, O. S. (2007), Financial Literacy and Planning: Implications for Retirement Wellbeing, Working Paper, Pension Research Council, The Wharton School.

Lusardi, A. and Tufano, P. (2015), Debt literacy, financial experiences, and over indebtedness, Journal of Pension Economics and Finance, 14, pp. 332-368. 
Mahdzan, N. S. and Tabiani, D. (2013), The Impact of Financial literacy on Individual Saving: An Exploratory study in the Malaysian context, Business \& Economics, 12(1), pp. 15-28.

Mandell, L. (2006), Financial literacy: Improving education results of the 2006 national Jump\$tart survey, Washington, DC: Jumpstart Coalition.

Mandell, L. (2008), Financial literacy of high school students, Handbook of Consumer Finance Research, pp. 163-183.

Ministerstvo školstva, vedy, výskumu a športu Slovenskej republiky, Ministerstvo financií Slovenskej republiky (2014), Národný štandard finančnej gramotnosti verzia 1.1. Bratislava: MŠVVŠ SR, retrieved from: https://www.minedu.sk/data/att/6152.pdf.

Montanaro, P. and Romagnoli, A. (2016), Financial literacy of Italian teens and family's background: evidence from PISA 2012, Questioni di Economia e Finanza, retrieved from: http://www.bancaditalia.it/pubblicazioni/qef/2016-0335/QEF_335_16.pdf.

President's Advisory Council on Financial Literacy (2008), 2008 Annual report to the President, Washington, DC: The Department of the Treasury, retrieved from http://www.treasury.gov/resource-center/financial education/ Documents/ PACFL_ANNUAL_REPORT_1-16-09.pdf.

Remund, D. L. (2010), Financial literacy explicated: The case for a clearer definition in an increasingly complex economy, Journal of Consumer Affairs, 44(2), pp. 276-295.

Rose, P. S. (1994), Peněžni a kapitálové trhy, Praha: Viktória Publishing.

Rose, P. S. (2002), Commercial bank management, The McGraw-Hill Companies, New York.

van Rooij, M., Lusardi, A., and Alessie, R. (2011), Financial literacy and stock market participation, Journal of Financial Economics, 101(2), pp. 449-472.

Titko, J., Lace, N., \& Polajeva, T. (2015), Financial Issues Perceived by Youth: Preliminary Survey for Financial Literacy Evaluation in the Baltics, Oeconomia Copernicana, 6(1), pp. 75-98, DOI: http://dx.doi.org/10. 12775/OeC.2015.004.

Vravec, J. (2014), Analýza úrovne finančnej gramotnosti a finančnej situácie obyvatel’ov východného Slovenska, Finančné trhy 4, pp. 1-10, retrieved from: http://www.derivat.sk/files/2014\%20financne\%20trhy/Okt_2014_FT_AnalyzaUrovne\% 20fin.\%20gramotnosti_Vravec.pdf

Walstad, W. B., Tharayil, A. and Wagner, J. (2016), Financial Literacy and Financial Education in High School, Handbook of Consumer Finance Research, pp. 131-140.

http://www.nextfuture.sk/financie/clanky/financna-gramotnost-slovaci-si-viac-veria-akovedia/

http://www.socscistatistics.com/tests.

http://www.socscistatistics.com/tests/ztest/Default2.aspx.

http://www.svet-komunikacie.sk/index.php?ID=13100.

http://www.psfv.cz/assets/cs/media/PSFV_2015_Vysledky-mereni-financni-gramotnosti.pdf. 